\title{
Effects of Safety Climate, Safety Attitude, and Safety Performance on Firm Performance: A Study of an Automobile Firm
}

\author{
Subhash C. Kundu ${ }^{1}$, Bhawana Yadav ${ }^{1} \&$ Anshul Yadav ${ }^{1}$ \\ ${ }^{1}$ Haryana School of Business, Guru Jambheshwar University of Science and Technology, Hisar-125001, \\ Haryana, India \\ Correspondence: Bhawana Yadav, Haryana School of Business, Guru Jambheshwar University of Science and \\ Technology, Hisar-125001, Haryana, India. E-mail: bhawanaydv@gmail.com
}

Received: September 18, 2016

Accepted: October 9, 2016 Online Published: November 20, 2016

doi:10.5539/ijbm.v11n12p135

URL: http://dx.doi.org/10.5539/ijbm.v11n12p135

\begin{abstract}
This study investigates the relationship between safety climate, safety attitude and firm performance and the mediating effects of safety performance. The study is based on the 102 respondents from an automobile manufacturing plant operating in Haryana, India. Regression analysis was used to assess the relationship between independent, mediating, and dependent variables. The results of our study supported the framed hypotheses. Safety performance mediated between safety climate and firm performance, safety attitude and firm performance.
\end{abstract}

Keywords: safety climate, safety attitude, safety performance, firm performance, India

\section{Introduction}

Recently the critical issue related to human resource management is occupational health and safety. Occupational health and safety programs are aimed to provide a safe and healthy working environment. Health and safety system needs a continuous effort to get proper growth (Roche, 2014). The achievement of any business largely depends on its manpower with regard to their specialized skills, optimistic attitude, job satisfaction, and contribution in quality activities (Huppert \& Wittington, 2005). The major aspect of corporate social responsibility (CSR) is related with health and safety of the workforce so that employees' feel secured and motivated (Kundu \& Gahlawat, 2015) because occupational health and safety is one of the serious issues faced by small and medium size firms (Aziz et al., 2015).

An organization must maintain a safe and healthy environment and it must build a strong base with a clear vision of future and specific means by which they will achieve it. Industries can maintain and achieve the competitive advantage by focusing on health and safety issues by implementing the Factory Act at the workplace (Hofmann et al., 1995). By providing safety training to the employees, employers establish a safe environment, which thereby encourage them to work safely (Subramaniam et al., 2016). Many industries which are on the growing stage do not focus on health and safety practices (Mearns et al., 2003). The numbers of work-related injuries or fatalities per year in a specific occupation give credence to the growing field of research and to entice more researchers to approach this burgeoning area (Lauren et al., 2012).

In this period of liberalization, several measures have been undertaken to increase the growth and development in every area but nothing substantial has been done regarding working conditions of workers which are still lacking (Gupta et al., 2008). Many policies are made by the Indian government and corporate sector but the big issue is that there is lack of proper implementation of these policies that is why; injuries and illness are increasing in every sector (Hofmann \& Stetzer, 1996). But the question is that in a developing country like India, where many industries are still in their infancy stage, can health and safety practices influence the performance of organizations under the background of economic liberalization and market globalization? Employer is responsible for improving the technology, reducing the accidents at workplace, creates a suitable environment, and boosts the safety awareness among all workers (Robson et al., 2007). There are so many economic and social reinforcements in the daily life of employees but no improvement has been done in the conditions of health and safety at workplace. Full involvement of employers and workers are required for advancement for health and safety (Sharma, 2001). Yadav et al. (2015) have explored the reasons of incidents and accidents at the workplace and provide necessary implications for the development of workers' safety in construction sector. 
Occupational health and safety measures include legal imperative, ethical concerns, industrial relations, and financial performance (Beriha et al., 2012). Every organization should implement the occupational health and safety policies which will help in enhancing the performance of workers (Hinze, 1997). Now-a-days many countries have created policies that should be followed by the employers to take care of the health and safety of employees by providing a physical environment of the workplace that has a direct impact on health and safety (Weil, 1991). Based on the survey of manufacturing industry, Kundu et al. (2015) have revealed that safety climate is positively and significantly related to safety attitude.

Indian labour organization data shows that every year approximately 4,30,000 people die due to workplace accidents. In India, many fatal accidents occur every day at the workplace (Pandita, 2009). With the passage of time, many factors i.e. social and economical have been improved but the health and safety status remained the same, which has brought the new problems (Marmot \& Wilkinson, 2006). Workers are the life line of any organization; if appropriate safety measures are not taken then, it will directly affect the production of the organization (Cascio, 2006). Literature found that very few studies have been done on the occupational safety (Legg et al., 2015). Therefore, this study is mainly undertaken to assess whether safety performance mediates the relationship between safety climate and safety attitude, and firm performance. The study also aims to assess the effects of safety climate and safety attitude on safety performance, and firm performance in a manufacturing organization.

\section{Review of Literature and Hypotheses Formulation}

\subsection{Safety Climate}

Safety climate influences the effectiveness of safety management sources i.e. rules, practices, and process. Safety climate is used as an indicator of safety culture (Cox \& Cheyne, 2000). Safety climate needs quantitative measures (Dension, 1996). Bailey et al. (2015) have opined that safety climate is related to mental and physical health of workers. History of the safety climate investigates the association between safety climate and safety results i.e. conformity with safe working practices and accidents (Byrom \& Corbridge, 1997). Different approaches of safety climate are firmly associated with self reported safety behaviors and these behaviors are directly related with accidents (Hofmann \& Stetzer, 1996; Hayes et al., 1998; Griffin \& Neal, 2000; Neal et al., 2000). Kumar et al. (2015) have observed that the dimension related to safety performance is helpful to the management in realizing the safety climate progress. Hellemans and Lapthorn (2016) have explored that pleasure at work is a contributer in understanding their workability.

\subsection{Safety Attitude}

Safety attitude is concerned with beliefs, perceptions, and values that employees hold regarding safety in the work area (Cox, 1991). Safety attitude is a reflection of an individual's perception relating to safety policies, procedures, and practices (Rundmo \& Hale, 2003; Neal \& Griffin, 2004), including one's personal obligation to and sense of individual duty towards safety. Safety attitudes are categorically linked to but separate from the group- or organizational-level safety climate (Neal \& Griffin, 2004) or shared employee cognizance of organizational policies, systems, and practices relating to safety, which can be encapsulated as the antecedent of safety over productivity (Zohar, 2002).

Cox (1991) has given the five factors to support the employee's safety attitude. These five factors are effective measure for safety, duty of individual for safety, safe work environment, personal protection, and personal skepticism. If the employees do not have the proper knowledge, attitude, and behavior about the health and safety practices then all the safety measures might be unsuccessful in the workplace (Raouf \& Dhillon, 1995).

\subsection{Safety Performance}

Goldenhar et al. (2003) have suggested that more demand of work is the major reason of injuries and accidents at the workplace. Few studies have investigated the impact of safety management system on safety performance and have suggested that a good safety system has a positive effect on safety performance (Teo et al., 2005; Choudhry et al., 2009). Good safety training is also found to be positively related with employees' safety performance (Mohanty \& Lakhe 1998; Kitapci \& Sezen 2007; Levine \& Toffel, 2010; Zhang, 2012). In the same way, a growing body of evidence suggests that safety training is an important forecaster of safety performance (Jaselskis et al., 1996). The studies have demonstrated that efficient training plans are connected with both production and organizational performance (Harel \& Tzafrir, 1999; Bartel et al., 2004). Likewise, firms with the better training programme reduce the accidents and increase the productivity in the workplace (Glendon \& Litherland, 2001; Mayze \& Bradley, 2008). Cheng et al. (2015) have revealed that presence of written safety policy is positively related to safety performance. Fleming and Lardner (1999) have also stated that safety 
practices help to enhance the performance by decreasing accidents, injuries and other unfavorable conditions for employees. Different instruments have been used to measure the safety performance that helps in monitoring business safety system, which is directly related to organization performance (Karanika, 2016).

\subsection{Firm Performance}

Black and Lynch (2001) have confirmed that workplace environment and implementation of practices related to workplace safety and health have positive impact on firm performance. In other studies, researchers have suggested that the involvement of group in work experienced fewer accidents then the individual employee (Askenazy, 2001; Brenner et al., 2004; Askenazy \& Caroli, 2006). In the contrast of this, Dawson et al. (2011) have showed that instead of worker it is management responsibility for reducing the accidents and manage the health and safety practices in the business. Kelly et al. (2008) recommended that proper method and technique of safety helps to enhance the employees' performance. It has been observed that irregular working hours at the work area effect the employees mental health and create the risk of injury that decrease the worker productivity (Caroli \& Van Reenen, 2001).

\subsection{Relationship between Safety Climate, Safety Attitude, Safety Performance, and Firm Performance}

Few studies explain the relationship between safety climate and safety performance and safety performance is an indicator of safety climate (Dahl \& Olsen, 2013). Safety climate is termed as a forecasting of safety performance (Cox \& Cheyne, 2000). Numerous authors believe that lesser accidents and workplace injuries create positive perception of workers about the safety performance (Zohar, 1980; Guastello, 1989; Guastello, 1991; Donald \& Canter, 1994). If workers do not feel satisfied then they can report poor safety performance (Murray et al. 1997). Safety climate controls the accidents and injuries in the workplace and increase the safety performance (Mearns et al., 2001).

Smith and Wadsworth (2009) indicate that there is a strong relationship between the safety attitude and safety performance. Unsafe attitude of workers is the main reason behind accidents at the work place (Mearns et al., 1998). Several studies suggested that production will be the higher and accidents will be the lesser if organization has the positive safety attitude (Runmado, 2000).

Safety climate is positively related to the firm performance. The reason for this action is top management and peer support individuals and groups (Morrison \& Phelps, 1999). Healthy workplace environment brings competitive gain for the organization (Sullivan, 2004) i.e. financial benefits (Dorman, 2000; Koningsveld, 2005). A study indicates that one's personal action is related to better firm performance (Wall et al., 1992). Besides top management, the trade union has also realized that good working environment leads to better firm performance and productivity (Boles et al., 2004; Greef et al., 2004).

Healthy workplace environment provides a competitive advantage to the organization (Sullivan, 2004). Tam and Fung (1998) based on the study of 45 construction companies have explored that high level of awareness among employees decrease the accidents rates at the workplace which thereby increasing the safety performance. In addition, Lee (1991) has stated that new workers need to orientate about the rules and policies which thereby increase the firm performance.

Health and safety environment comprises of various health and safety measures that show the positive effect on labor productivity. Positive health and safety performance has provided competitive advantages to the firm (Greef et al., 2004). Organization investment in occupational safety and health gives the better safety performance as a return for the future (Yrjänheikki, 2011). Cooper (2000) has found in their study that lower accidents and absenteeism rates as an indicator of safety performance shows significant and positive effect on financial performance. Safety performance and firm performance used as a dependent variable in the few studies (Osterman, 1994).

Numerous studies have attempted to discover the significant relationship between safety climate and firm performance (Zohar \& Luria, 2005). Antonsen (2009) has reported that safety performance acts as a mediator between safety climate and firm performance. Bourne et al. (2003) have stated that a positively perceived safety climate enhanced safety performance which, in turns lead to firm performance. Pidgeon (1991) has opined that mediating variable that holds a more universal approach on individual attributes i.e. attitude, explained the relationship between safety attitude and firm performance. Mc Dlarmid and Condon (2005) have observed a significant and positive relationship between safety attitude and safety performance which, consequently enhanced the firm performance. On the basis of literature review, the following hypotheses were set in this study:

Hypothesis 1: Safety climate is positively related to safety performance.

Hypothesis 2: Safety attitude is positively related to safety performance. 
Hypothesis 3: Safety climate is positively related to firm performance.

Hypothesis 4: Safety attitude is positively related to firm performance

Hypothesis 5: Safety performance is positively related to firm performance.

Hypothesis 6: Safety performance mediates the positive relationship between safety climate and firm performance.

Hypothesis 7: Safety performance mediates the positive relationship between safety attitude and firm performance.

\section{Research Methodology}

\subsection{Sample and Data}

In the present study, a questionnaire survey approach was used to gather the data. Primary data were gathered from 102 respondents of an automobile manufacturing plant that was situated in Haryana. Data were collected and analyzed.

Table 1. Sample and demographics based on individuals and organization

\begin{tabular}{|c|c|c|c|c|c|}
\hline Variables & Categories & Numbers & Percentage & Average & Yes/No \\
\hline \multirow[t]{3}{*}{ 1. Gender } & Male & 95 & 93.1 & & \\
\hline & Female & 07 & 6.9 & & \\
\hline & Total & 102 & 100 & & \\
\hline \multicolumn{3}{|l|}{ 2. Total work experience } & & 7.2 & \\
\hline \multicolumn{2}{|l|}{$\begin{array}{l}\text { 3. Experience in the present } \\
\text { organization }\end{array}$} & & & 2.7 & \\
\hline \multirow[t]{6}{*}{ 4. Age of employees } & Below 25 years & 37 & 36.3 & & \\
\hline & $26-30$ years & 30 & 29.4 & & \\
\hline & $31-40$ years & 22 & 21.6 & & \\
\hline & $41-50$ years & 12 & 11.8 & & \\
\hline & $51-60$ years & 01 & 1.0 & & \\
\hline & Total & 102 & 100 & & \\
\hline \multicolumn{3}{|l|}{ 5. Average age of employees } & & 30.62 & \\
\hline \multirow[t]{3}{*}{ 6. Designation } & HR & 06 & 5.9 & & \\
\hline & NON-HR & 96 & 94.1 & & \\
\hline & Total & 102 & 100 & & \\
\hline \multicolumn{5}{|c|}{ 7. Organization has a HRM department. } & Yes \\
\hline \multicolumn{5}{|c|}{ 8. Organization has a formalized strategic plan } & Yes \\
\hline \multicolumn{5}{|c|}{ 9. Organization has adopted a strategic HRM within the framework of strategic plan } & Yes \\
\hline \multicolumn{5}{|c|}{ 10. Organization has a health and safety Department } & Yes \\
\hline \multicolumn{5}{|c|}{ 11. Health and safety department properly aligned with HR and other departments } & Yes \\
\hline \multicolumn{5}{|c|}{ 12. Health and safety department is properly staffed or not } & Yes \\
\hline \multicolumn{5}{|c|}{ 13. Organization has written health and safety policy } & Yes \\
\hline \multicolumn{5}{|c|}{ 14. Organization adopted health and safety management system } & Yes \\
\hline \multicolumn{5}{|c|}{ 15. Organization has health and safety inspector/supervisor/manager } & Yes \\
\hline \multicolumn{5}{|c|}{ 16. Organization display a copy of the factory act at a prominent place } & Yes \\
\hline
\end{tabular}

Table 1 shows that the sample consists of both male (93.1\%) and female (6.9\%). Average of total work experience of respondent employees/managers was 7.2 years whereas average of experience in the present organization of the respondent employees/managers was 2.7 years. $36.3 \%$ employee/managers were found below 25 years, $29.4 \%$ employee/managers were between $26-30$ years, $21.6 \%$ were in $31-40$ years, $11.8 \%$ were in 41-50 years, and $01 \%$ belonged to the category of 51-60 years. Average age of total respondent employees/managers was 30.62 years. The sample included $5.9 \%$ of HR managers and $94.1 \%$ of non-HR employees/managers.

\subsection{Control Variables}

Two variables i.e. gender and total work experience, were used as control variables. 


\subsection{Safety Climate and Safety Attitude (Independent Variables)}

In this study, we had taken two independent variables i.e. safety climate and safety attitude. Safety climate included three items i.e. 'management places strong emphasis on workplace health and safety', 'safety is given high priority by management' and 'management consider safety to be important' (Neal et al. 2006). Cronbach $\alpha$ for this scale was 0.930 . Safety attitude included three statements i.e. 'my organization knows how to improve safety at our working area', 'my organization cares for workers' health and work safety' and 'my organization requires the safe working procedure when they are working' (Hung et al. 2011). Cronbach $\alpha$ for this scale was 0.922. Respondents were asked to assess their opinions on a five-point Likert scale ranging from strongly disagree (1) to strongly agree (5).

\subsection{Safety Performance (Mediating Variable)}

Safety performance was measured by using three items scale. The items of safety performance were taken from the study of Beriha et al. (2012). Responses were taken on a five-point likert scale ranging from 1 (strongly disagree) to 5 (strongly agree). The items were 'personal injury in the organization was low', 'material damage is low in the organization', and 'overall accidents at the work place is also very low'. Cronbach $\alpha$ for this scale was 0.847 .

\subsection{Firm Performance (Dependent Variable)}

Firm performance was measured with ten items scale developed and used by Khandwalla (1977) and Som (2008). Responses were taken on a five-point scale ranging from 1 (much lower) to 5 (much higher). The items were 'product/ service quality', 'productivity', 'profitability', 'customer satisfaction level', 'market share', 'growth of sales revenue', 'innovation', 'efficiency of operations', 'organizational flexibility', and 'overall firm performance'. Cronbach $\alpha$ for this scale was 0.942 .

\subsection{Statistical Techniques}

SPSS for Windows 13.0 version was used to analyze the data. Separate factor analyses were used to bring out the dimensions related to safety climate, safety attitude, safety performance, and firm performance. Multiple regression analysis was used to explain the relationship between the safety climate, safety attitude, safety performance, and firm performance of the organization. Initially, correlation was used to find the association between safety climate, safety attitude, safety performance and firm performance. Mean and standard deviations were also used.

\section{Results}

Three variables related to safety climate, three related to safety attitude, and three variables related to safety performance were subjected to the principal components factor analysis separately with varimax rotation by using the criterion that factors with the eigen value greater than 1.00 will be retained. For stating the factors clearly, loading exceeding 0.80 were considered and included in factors. Safety climate had eigen value 2.314 and total percent of variance of this factor was 87.76. Safety attitude showed eigen value 2.633 and 86.21 percent of total variance. Safety performance had eigen value 2.609 and percent of variance of this factor was 77.19 .

Table 2. Factor loadings of varimax rotated principal components

\begin{tabular}{|c|c|c|c|c|}
\hline Items & Loadings & Eigen value & $\%$ of Variance & Cronbach Alpha \\
\hline \multicolumn{5}{|l|}{ Factor analysis I } \\
\hline Safety climate & & 2.314 & 87.76 & .930 \\
\hline $\begin{array}{l}\text { Management places a strong emphasis on } \\
\text { workplace health and safety. }\end{array}$ & .927 & & & \\
\hline Safety is given a high priority by management. & .952 & & & \\
\hline Management considers safety to be important. & .932 & & & \\
\hline \multicolumn{5}{|l|}{ Factor analysis II } \\
\hline Safety attitude & & 2.633 & 86.21 & .922 \\
\hline $\begin{array}{l}\text { My organization knows how to improve } \\
\text { safety at our working area. }\end{array}$ & .928 & & & \\
\hline $\begin{array}{l}\text { My organization cares for worker's } \\
\text { health and work safety. }\end{array}$ & .935 & & & \\
\hline My organization requires workers to & .922 & & & \\
\hline
\end{tabular}




$\begin{aligned} & \text { follow the safe working procedures when they } \\ & \text { are working. }\end{aligned}$
Factor analysis III
Safety performance
Personal injuries in the organization are
very low
Material damage is low in the organization.

Ten items related to firm performance were again subjected to factor analysis. Emerged one factor on firm performance had eigen value 5.650 and percent of total variance of this factor was 66.50 . Safety climate, safety attitude, safety performance, and firm performance were considered as scales and used for further analysis. Safety climate was loaded significantly with three practices/variables like emphasis on workplace health and safety, safety is given high priority and safety is important for the management. Safety attitude was loaded with three statements i.e. improving safety at working area, organization cares for workers' health, and workers follow the safe working procedure. Safety performance loaded with low personal injuries, low material damage and low overall accidents level at the workplace. Firm performance loaded with ten variables i.e. product/service quality, productivity, profitability, customer satisfaction level, market share, growth of sales revenue, innovation, efficiency of operations, organizational flexibility and overall firm performance.

Table 3 shows the correlations, standard deviations and means of various variables. There was a significant correlation $\left(r=.419^{* *}\right)$ between safety climate and safety performance. Safety attitude was also significantly $\left(\mathrm{r}=.293^{* *}\right)$ correlated with safety performance. In the same way, there was a significant correlation $\left(\mathrm{r}=.252^{*}\right)$ between safety climate and firm performance. Safety attitude was also significantly correlated $\left(\mathrm{r}=.165^{*}\right)$ with firm performance. Safety performance and firm performance was also significantly correlated $\left(\mathrm{r}=.593^{* *}\right)$.

Table 3. Shows the correlations, standard deviation and means of various variables

\begin{tabular}{lllllccccc}
\hline Items & Items & Mean & SD & GEN & TWE & SC & SA & SP & FP \\
\hline Gender (GEN) & - & .930 & .256 & - & - & & & & \\
Total work experience (TWE) & - & 7.88 & 6.31 & $.225 *$ & - & & & \\
Safety climate(SC) & 3 & 3.66 & 0.86 & .060 & .049 & - & & \\
Safety attitude(SA) & 3 & 3.99 & 1.43 & .068 & -.060 & $.399 * *$ & - & & \\
Safety performance(SP) & 3 & 3.75 & 0.76 & -.089 & -.070 & $.419 * *$ & $.293 * *$ & - & $.593 * *$ \\
Firm performance (FP) & 10 & 3.59 & 0.74 & .090 & -.162 & $.252^{*}$ & $.165^{*}$ &. \\
\hline
\end{tabular}

*Correlation is significant at the 0.05 level (2-tailed).

**Correlation is significant at the 0.01 level (2-tailed).

Table 4 and 5 show the results of regression analysis. Model 4a was a base model which incorporated the control variables basically used to explain the separate effects of control variables on safety performance. It was observed from the model $4 \mathrm{~b}$ that safety climate had a positive effect on safety performance $(\beta=.429, \mathrm{p} \leq 0.001)$ which explained $16.8 \%$ variance. So, the results supported the H1. It was analyzed from model $4 \mathrm{c}$ that safety attitude had significant effect on safety performance $(\beta=.378, \mathrm{p} \leq 0.001)$ which explained $12.6 \%$ variance. So, 
the $\mathrm{H} 2$ was accepted.

Table 4. Results of regression analysis showing effects of safety climate and safety attitude on safety performance

\begin{tabular}{llll}
\hline Variable & SP & SP & SP \\
& Model 4a & Model 4b & Model 4c \\
\hline Gender & .077 & -.099 & $-.103 * *$ \\
Total work experience & -.053 & -.069 & -.030 \\
Safety climate & & $.429 * * *$ & $.378^{* * *}$ \\
Safety attitude & & & .152 \\
$\mathrm{R}^{2}$ & .010 & .193 & .126 \\
Adjusted $\mathrm{R}^{2}$ & -.010 & .168 & \\
${ }^{*} \mathrm{p}<0.05, * * \mathrm{p}<0.01, * * * \mathrm{p}<0.001$. & & &
\end{tabular}

Model 5a was a base model which incorporated the control variables basically used to explain the separate effects of control variables on firm performance. It was observed from the model $5 \mathrm{~b}$ that safety climate had a positive effect on firm performance which explained $8 \%$ variance and the value of beta coefficient was $(\beta$ $\left.=.254^{* *}, \mathrm{p} \leq 0.01\right)$. So, H3 was accepted. Model $5 \mathrm{c}$ showed that safety attitude had significant effect which explained $8.8 \%$ variance on firm performance and value of beta coefficient was $\left(\beta=.271^{* *}, p \leq 0.01\right)$. So, the H4 was supported. In the model $5 \mathrm{~d}$, safety performance had significant effect on firm performance $\left(\beta=.598^{* * *}\right.$, $\mathrm{p} \leq 0.001$ ) which explained $37.8 \%$ variance. So, the $\mathrm{H} 5$ was accepted.

To examine the mediation effects, both independent and mediating variables entered simultaneously in the regression equation of the model $5 \mathrm{e}$. In this model, $\beta$ coefficient of safety climate came out insignificant and the mediating variable i.e. safety performance remained significant $\left(\beta=.598^{* * *}, \mathrm{p} \leq 0.001\right)$. The predictors explained $37.1 \%$ of the variance on model $5 \mathrm{e}$. So, H6 was supported. In this way, safety performance mediates fully between safety climate and the firm performance. In model $5 \mathrm{f}$, when both the second mediator (safety attitude) and safety performance were entered simultaneously, it was found that safety performance significantly $\left(\beta=.578^{* * *}, \mathrm{p} \leq 0.001\right)$ impacted the firm performance where as the independent variable i.e. safety attitude came out insignificant. The predictors here explained $37.4 \%$ of the variance. Hence, the results supported the hypothesis 7 . So, safety performance mediates fully between safety attitude and the firm performance.

Table 5. Regression analysis showing effects of safety climate, safety attitude and safety performance and firm performance

\begin{tabular}{lllllll}
\hline Variables & FP & FP & FP & FP & FP & FP \\
& $\begin{array}{l}\text { Model } \\
\text { 5a }\end{array}$ & Model 5b & Model 5c & Model 5d & $\begin{array}{l}\text { Model } \\
\text { Model }\end{array}$ \\
\hline Gender & 0.133 & 0.120 & 0.114 & 0.179 & 0.179 & 0.174 \\
Total work experience & -0.192 & -0.202 & -0.176 & -0.161 & -0.161 & -0.159 \\
Safety climate & & $0.254^{* *}$ & & & -0.002 & 0.052 \\
Safety attitude & & & $0.271^{* *}$ & & & $0.578^{* * *}$ \\
Safety performance & & & & $0.598^{* * *}$ & $0.598^{* * *}$ & 0.399 \\
$\mathrm{R}^{2}$ & 0.043 & 0.108 & 0.116 & 0.396 & 0.396 & 0.374 \\
Adjusted $\mathrm{R}^{2}$ & 0.023 & 0.080 & 0.088 & 0.378 & 0.371 & \\
\hline
\end{tabular}

$* \mathrm{p}<0.05,{ }^{* *} \mathrm{p}<0.01, * * * \mathrm{p}<0.001 ; \mathrm{FP}=$ Firm performance.

\section{Discussion and Conclusions}

Safety must be considered as transformational factor (Mezirow, 1991) that employees should use their safety experiences in different situations and change their behaviors and attitudes according to the workplace conditions (Sochen, 1972) and also take learning from their mistakes for the future. For improving both safety and firm performance, every organization should improve the safety climate for achieving its goals. In this study we have used multiple regression analysis on a data of 102 respondents from an automobile manufacturing 
company.

The results of the study provide a strong indication that both safety climate and safety attitude contribute to safety performance. Tan-Wilhelm et al. (2000) have suggested that more positive safety climate reduces the accidents and enhances the safety performance. The logic behind this finding is that safety climate strongly related to safe workplace environment. When employees perceive that their organization has adopted such practices, their attitude towards the safety increases and consequently boosts the safety performance as well as firm performance. Rundmo (2000) also concluded in the study that there was a strong and positive relationship between safety attitude and safety performance. The finding might be the result of good safety climate and environment provided by the organization. A perceived positive safety attitude reduces human error which thereby enhances the firm performance (Dember, 1989).

Finally, we proceeded with testing the mediation effect of safety performance in the relationship between safety climate, safety attitude, and firm performance. The results are in favor of stated hypotheses, which showed a positive impact of safety climate and safety attitude on safety performance and in turn safety performance has positive effect on the firm performance. In addition to that after analyzing a sample of 657 respondents, Rodrigo and Grimm (2010) have explored that financial performance of an organization is positively related to safety performance. Safety attitude has a significant and positive effect on safety performance (Kundu et al., 2015). If the employer perceive positive attitude towards safety warning, which reduces the accidents rate and it increases the safety performance (Marcus \& Nichols, 1999).

\section{Implications, Limitations and Future Directions}

This study has some policy implications for the organizations and HR managers. A key implication is that management that provides good safety climate and environment will reduce the accidents which in turn will enhance the safety performance as well as firm performance. The study suggests that to encourage and develop the desirable attitudes and behaviours in employees, it is important to plan and implement the suitable health and safety practices that are important for the safety of the employees. It is further pertinent for the HR mangers and safety managers to comply with health and safety standards as provided by laws applicable in context. Duty of safety managers should be properly defined so that implementation of safety practices can promote safety climate.

This study has certain limitations that offer certain paths for theoretical and experimental studies. The very first limitation of the study is that the data was gathered through a particular instrument, i.e. survey, surely there were chances of common method variance in our findings. Sequentially to verify that possibility, Harman's (1976) single-factor test was applied to all the variables that used in the study. A principal factor component revealed three factor accounted $73.84 \%$ of variance where as first factor explained $35.17 \%$ of variance, so common method variance was not a serious issue in our study (Podsakoff \& Organ, 1986).

However future studies' data should be gathered from the different sources and different time intervals by framing a separate questionnaires for the dependent and independent variables. Further limitation of this study is that we have taken the one mediating variable i.e. safety performance. It mediates between safety climate, safety attitude and firm performance. Future researchers may incorporate other mediators like safety motivation, safety participation, safety compliance, etc. Future studies can also systematically observe the differences between Indian companies and MNCs as well as manufacturing and services. The data of the study is comparatively small and limited to one manufacturing company only. Future studies may be conducted by covering large number of companies with large sample size to generalize the results. Cross sectional study is the other limitation of our study. To overcome this limitation, longitudinal study must be carried out to gather the data from repetitive observations.

\section{References}

Antonsen, S. (2009). The Relationship between culture and safety on off shore supply vessels. Safety Science, 47(8), 1118-1128. http://dx.doi.org/10.1037/a0028675

Askenazy, P., \& Caroli, E. (2006). Innovative Work Practices, Information Technologies and Working Conditions: Evidence for France. Journal of Economy and Society, 49(4), 544-565.

Aziz, A. A., Baruji, M. E., Abdullah, M. S., Him, N. F. N., \& Yusof, N. M. (2015). An initial study on accident rate in the workplace through occupational safety and health management in sewerage services. International Journal of Business and Social Science, 6(2), 29-255.

Bailey, T. S., Dollard, M. F., McLinton, S. S., \& Richards, P. A. M. (2015). Psychosocial safety climate, psychosocial and physical factors in the aetiology of musculoskeletal disorder symptoms and workplace 
injury compensation claims. Work \& Stress, 29(2), 190-211. http://dx.doi.org/10.1080/02678373.2015.1031855

Bartel, A., Freeman, R., Ichniowski, C., \& Kleiner, M. M. (2004). Can a work organization have an attitude problem? The impact of workplaces on employee attitudes and economic outcome. Industrial and Labor Relations Review, 52(3), 539-564. http://dx.doi.org/10.3386/w9987

Beriha, G., Patnaik, B., \& Mahapatra, S. (2012). Assessment of occupational health practices in Indian industries, A neural network approach. Journal of Modelling in Management, 7(2), 180-200. http://dx.doi.org/10.1108/17465661211242804

Black, S. E., \& Lynch, L. M. (2001). How to compete: The impact of workplace practices and information technology on productivity. Review of Economics and Statistics, 83(3), 434-445. http://dx.doi.org/10.1111/j.0036-9292.2005.00349.x

Boles, M., Pelletier, B., \& Lynch, W. (2004). The relationship between health risks and work productivity. Journal of Occupational Environmental Medicine, 46(7), 737-745.

Bourne, M., Neely, A., Platts, K., \& Mills, J. (2003). The success and failure of performance measurement initiatives: perceptions of participating managers. International Journal of Operations and Production Management, 22(11), 1288-1310. http://dx.doi.org/10.1177/15357602025004004

Brenner, M., Fairris, D., \& Ruser, J. (2004). Flexible work practices and occupational safety and health: Exploring the relationship between cumulative trauma disorders and workplace transformation. A Journal of Economy and Society, 43(1), 242-266. http://dx.doi.org/10.1111/ j.0019-8676.2004.00325.x

Bronkhorst, B., \& Vermeeren, B. (2016). Safety climate, worker health and organizational health performance. International Journal of Workplace Health Management, 9(3), 270-289. http://dx.doi.org/10.1108/IJWHM-12-2015-0081

Byrom, N., \& Corbridge, J. (1997). A tool to assess aspects of an organisations health \& safety climate. Proceedings of International Conference on Safety Culture in the Energy Industries, Aberdeen, Scotland.

Caroli, E., \& Van Reenen, J. (2001). Skill-Biased Organizational Change? Evidence from a Panel of British and French Establishments. Quarterly Journal of Economics, 16(4), 1449-1490.

Cascio, W. F. (2006). Managing Human Resources: Productivity, Quality of Work Life, Profits (7th ed.). New York, United States: McGraw-Hill.

Cheng, E. W. L., Ryan, N., \& Kelly, S. (2015). Exploring the perceived influence of safety management practices on project performance in the construction industry. Safety Science, 50, 363-369.

Choudhry, R. M., Fang, D., \& Lingard, H. (2009). Measuring safety climate of a construction company. Journal $\begin{array}{llll}\text { of Construction } \quad \text { Engineering } & \text { and }\end{array}$ http://dx.doi.org/10.1061/(ASCE)CO.1943-7862.0000063

Cooper, M. D. (2000). Towards a model of safety culture. Safety Science, 36, 111-136.

Cox, S. J., \& Cheyne, A. J. T. (2000). Assessing safety culture in offshore environments. Safety Science, 34, 111-129. http://dx.doi.org/10.1016/S0925-7535(00)00009-6

Cox, S., \& Cox, T. (1991). The structure of employee attitudes to safety: A European example. Work \& Stress, 5 , 93-106. http://dx.doi.org/10.1080/02678379108257007

Dahl, O., \& Olsen, E. (2013). Safety compliance on offshore platforms: A multi-sample survey on the role of perceived leadership involvement and work climate. Safety Science, 54, 17-26. http://dx.doi.org/10.1016/j.ssci.2012.11.003

Dawson, T. P., Jackson, S. T., House, J. I., Prentice, I. C., \& Mace, G. M. (2011). Beyond predictions: Biodiversity conservation in a changing climate. Safety Science, 332, 53-58. http://dx.doi.org/10.1126/science.1200303.

Dember W. N., Martin S. H., \& Hummer, M. K. (1989). The measurement of optimism and pessimism. Current Psychology Reserve Review, 8, 102-119.

Dension, D. R. (1996). What is the difference between organizational culture and organisational climate. A native's point of view on a decade of paradigm wars. Academy of Management Review, 21, 619-654. http://dx.doi.org/10.5465/AMR.1996.9702100310 
Donald, I., \& Canter, D. (1994). Employee attitudes and safety in the chemical industry. Journal of Loss Prevention in the Process Industries, 7, 203-208. http://dx.doi.org/10.1016/0950-4230(94)80067-7

Dorman, P. (2000). The economics of safety, health, and well-being at work: An overview. Geneva: ILO.

Fleming, M., \& Lardner, R. (1999). Happiness and productivity revisited. Journal of Organizational Behavior, 20(1), 25-30.

Glendon, A. I., \& Litherland, D. K. (2001). Safety climate factors, group differences and safety behavior in road construction. Safety Science, 39(3), 157-188. http://dx.doi.org/10.1016/S0925-7535(01)00006-6

Goldenhar, L., Williams, L., \& Swanson, N. (2003). Modelling the relationship between job stressors and injury and near-miss outcomes for construction laboures. Work \& Stress, 17(3), 218-240. http://dx.doi.org/10.1080/02678370310001616144

Greef, M. D., Broek, K., Jongkind, R., Kenny, L., Shechtman, O., \& Kuhn, K. (2004). Quality of the working environment and productivity: Research findings and case studies. European Agency for Safety and Health at Work.

Griffin, M. A., \& Neal, A. (2000). Perceptions of safety at work: A framework for linking safety climate to safety performance, knowledge, and motivation. Journal of Occupational Health Psychology, 5, 347-358. http://dx.doi.org/10.1037fl1076-8998.5.3.347

Guastello, S. J. (1989). Catastrophe modeling of the accident process: Evaluation of an accident reduction program using the occupational hazards survey. Accident Analysis and Prevention, 21(1), 61-77. http://dx.doi.org/10.1016/0001-4575(89)90049-3

Guastello, S. J. (1991). Psychosocial variables related to transit safety: The application of catastrophe theory. Work \& Stress, 5(1), 17-28. http://dx.doi.org/10.1080/02678379108256999

Gupta, S. A., Kannan, K. P., \& Raveendran, G. (2008). India's common people: Who are they, how many are they and how do they live? Economic and Political Weekly, 43(11), 49-63.

Harel, G. H., \& Tzafrir, S. (1999). The effect of human resource management practices on the perceptions of organizational and market performance of the firm. Human Resource Management, 38(3), 185-199. http://dx.doi.org/10.1002/(SICI)1099-050X(199923)38:3<185::AID-HRM2>3.0.CO;2-

Harman, H. H. (1976). Modern Factor Analysis. Chicago, IL: University of Chicago Press.

Hayes, B. E., Perander, J., Smecko, T., \& Trask, J. (1998). Measuring perceptions of workplace safety: Development and validation of the Workplace Safety Scale. Journal of Safety Research, 29(3), 145-161. http://dx.doi.org/10.1016/S0022-4375(98)00011-5

Hellemans, C., \& Lapthorn, B. (2016). Antecedents of work ability in the cleaning sector. International Journal of Workplace Health Management, 9(3), 328-339. http://dx.doi.org/10.1108/IJWHM-11-2015-0062

Hinze, J. (1997). Construction safety. Prentice-Hall, Upper Saddle River, N.J.

Hofmann, D. A., Jacobs, R. R., \& Landy, F. (1995). High reliability process industries: Individual, micro, and macro organizational influences on safety influences on safety performance. Journal of Safety Research, 26(3), 131-149. http://dx.doi.org/10.1016/0022-4375(95)00011-E

Hung, Y. H., Tonya, S. J., \& Woodrow, W. (2011). Use of attitude congruence to identify safety interventions for small residential builders. Journal of Construction Management and Economics, 29(2), 113-130. http://dx.doi.org/org/10.1080/01446193.2010.521758

Huppert, F. A., \& Wittington, J. E. (2005). Positive mental health in individuals and populations. The Science of Well-being. Oxford, England: Oxford University Press.

Jaselskis, E. J., Anderson, S. D., \& Russell, J. S. (1996). Strategies for achieving excellence in construction safety performance. Journal of Construction Engineering and Management, 122, 61-70. http://dx.doi.org/10.1061/(ASCE)0733-9364(1996)122:1(61)

Karanika, N. (2016). Critical review of safety performance metrics. International Journal Business Performance Management, 17(3), 8-17.

Kelly, E., Kossek, E., Hammer, L., Durham, M., Bray, J., Chermack, K., Murphy, L., \& Kaskubar, D. (2008). Getting there from here: Research on the effects of work-family initiatives on work-family conflict and business outcomes. The Academy of Management Annals, 2(1), 305-349. http://dx.doi.org/10.1080/19416520802211610 
Khandwalla, P. N. (1977). The Design of Organizations. New York: Harcourt Brace Jovanovich.

Kitapci, H., \& Sezen, B. (2007). The effects of participation in decision making, individual improvement efforts and training on the quality of the product design process production planning and control. Journal of Occupational Health Psychology, 18(1), 3-8. http://dx.doi.org/10.1080/09537280600940580

Koningsveld, E. (2005). Participation for understanding: An interactive method. Journal of Safety Research, 36, 231-236. http://dx.doi.org/ org/10.1016/j.jsr.2005.06.004

Kumar, A., Jain N. K., \& Patel, P. (2015). Analysis of safety performance rating in thermal power plant. International Journal of Emerging Technology and Advanced Engineering, 5(1), 120-128.

Kundu, S. C., \& Gahlawat, N. (2015). Socially responsible HR practices and employees' intention to quit: The mediating role of job satisfaction. Human Resource Development International, 18(4), 387-406. http://dx.doi.org/10.1080/13678868.2015.1056500

Kundu, S. C., Yadav, B., \& Yadav, A. (2015). Effects of safety Climate and Safety Attitude on Safety Performance: A Study of an Indian Organization. Emerging horizons in Business and Management. Delhi: Victorious Publishers.

Lauren, A. M., Michelle, M. R., \& Huang, Y. H. (2012). The development of a conceptual model regarding the role of social modelling in safety behavior an integrated literature review. Theoretical Issues in Ergonomics Science, 13(3), 286-302. http://dx.doi.org/10.1080/10803548.2013.11077018

Lee, H. K. (1991). Safety Management: Hong Kong Experience. Lorrainelo Concept Design.

Legg, S. J., Olsen, K. B., Laird, I. S., \& Hasle, P. (2015). Managing safety in small and medium enterprises. Safety Science, 71, 189-196. http://dx.doi.org/10.1016/j.ssci.2014.11. 007

Levine, D. I., \& Toffel, M. W. (2010). Quality Management and Job Quality: How the ISO 9001 Standard for Quality Management Systems Affects Employees and Employers. Management Science, 56(6), 978-996. http://dx.doi.org/10.1287/mnsc.1100.1159

Marcus, A. A., \& Nichols, M. L. (1999). On the edge: Heeding the warnings of unusual events. Journal of Organization Science, 10, 482-499. http://dx.doi.org/10.1177/1086026613489034

Marmot, M., \& Wilkinson, R. G. (2006). Social deterninants of health (2nd ed.). Oxford, United Kingdom, Oxford University press.

Mayze, B. R., \& Bradley, L. M. (2008). Safety culture: A multilevel assessment tool for the construction industry (pp. 1-24).

McDiarmid, M. A., \& Condon, M. (2005). Organisational safety culture, climate and worker compliance with hazardous drug guidelines: Lessons from the blood-borne pathogen experience. Journal of Occupational and Environmental Medicine, 47(7), 740-749.

Mearns, K., Flin, R., Gordon, R., \& Fleming, M. (1998). Measuring safety climate on offshore installations. Work \& Stress, 12, 238-250. http://dx.doi.org/10.1080/02678379808256864

Mearns, K., Whitaker, S. M., \& Flin, R. (2001). Benchmarking safety climate in hazardous environments: A longitudinal, interorganizational approach. Risk Analysis, 21(4), 771-786. http://dx.doi.org/10.1111/0272-4332.214149

Mearns, K., Whitaker, S. M., \& Flin, R. (2003). Safety climate, safety management practice and safety performance in offshore environments. Safety Science, 41, 641-80. http://dx.doi.org/10.1016/S0925-7535(02)00011-5

Mezirow, J. (1991). Transformation theory and cultural context: A reply to clark and wilson. Adult Education Quarterly, 41(3), 188-192.

Morrison, E. W., \& Phelps, C. C. (1999). Taking charge at work: Extra role efforts to initiate workplace change. Journal of Academy of Management, 42, 403-419. http://dx.doi.org/0.2307/257011

Murray, M., Fitzpatrick, D. O., \& Connell, C. (1997). Fishermen's blues: Factors related to accidents and safety among new foundland fishermen. Work \& Stress, 11, 292-297. http://dx.doi.org/10.1080/02678379708256842

Neal, A., \& Griffin, A. (2006). A study of the lagged relationships among safety climate, safety motivation, safety behavior and accidents at individual and group levels. Journal of Applied Psychology, 91, 946-53. http://dx.doi.org/10.1037/0021-9010.91.4.946 
Neal, A., \& Griffin, M. A. (2004). Safety climate and safety at work. In M. R. Frone \& J. Barling (Eds.), The psychology of workplace safety. Washington, DC: American Psychological Association.

Neal, A., Griffin, M. A., \& Hart, P. M. (2000). The impact of organizational climate on safety climate and individual behavior. Safety Science, 34, 99-109. http://dx.doi.org/10.1016/S0925-7535(00)00008-4

Osterman, P. (1994). How common is workplace transformation and who adopts it? Industrial and Labor Relations Review, 47,173-188. http://dx.doi.org/10.1177/001979399404700202

Pandita, S. (2009). Status of occupational safety and health in India. Infochange Agenda, 15, 7-9.

Pidgeon, N. F. (1991). Safety culture and risk management in organizations. Journal of Cross-Cultural Psychology, 22(1), 129-140. http://dx.doi.org/10.1177/0022022191221009

Podsakoff, P. M., \& Organ, D. W. (1986). Self-Reports in Organizational Research: Problems and Prospects. Journal of Management, 12(4), 531-544. http://dx.doi.org/10.1177/014920638601200408

Raouf, A., \& Dhillon, B. S. (1995). Safety assessment. Luis London.

Robson, L. S., Clarke, J. A., Cullen, K., Bielecky, A., Severin, C., Bigelow, P. L., \& Mahood, Q. (2007). The effectiveness of occupational health and safety management system interventions: A systematic review. Safety Science, 45(3), 329-353. http://dx.doi.org/10.1016/j.ssci.2006.07.003

Roche, M. (2014). Guidelines for the Assurance of Safety, Security. Health and Environmental Protection.

Rodrigo, B., \& Grimm, C. M. (2010). Impact of motor carrier Firms' financial performance on safety performance. Transportation Journal, 49(4), 42-51.

Rodrigues, M. A., Arezes, P. M., \& Leão, C. P. (2015). Safety climate and its relationship with furniture companies' safety performance and workers' risk acceptance. Theoretical Issues in Ergonomics Science, 16(4), 412-428. http://dx.doi.org/10.1080/1463922X.2014.1003991

Rundmo, T. (2000). Safety climate, attitudes and risk perception. Safety Science, 34, 47-59. http://dx.doi.org/10.1016/S0925-7535(00)00006-0

Rundmo, T., \& Hale, A. R. (2003). Managers' attitudes toward safety and accident prevention. Safety Science, 41, 557-574. http://dx.doi.org/10.1016/S0925-7535(01)00091-1

Saunders, L. W., McCoy, A. P., Kleiner, B. M., Lingard, H., Cooke, T., Mills, T., \& Wakefield, R. (2016). International benchmarking for performance improvement in construction safety and health. Benchmarking: An International Journal, 23(4), 916-936.

Sharma, K. (2001). Management transformation towards safety. Journal of Delhi Business Review, 2(2), 43-45.

Smith, A. P., \& Wadsworth, E. J. K. (2009). Safety culture, advice and performance: The associations between safety culture and safety performance, health and wellbeing at an individual level, and safety culture, competent occupational safety and health advice, and safety performance at a corporate level-Report submitted to the IOSH Research Committee.

Sochen, J. (1972). The Unbridgeable Gap: Blacks and their Quest for the American Dream. Chicago, IL: Rand McNally.

Som, A. (2008). Innovative human resource management and corporate performance in the context of economic liberalization in India. The International Journal of Human Resource Management, 19(7), 1278-1297. http://dx.doi.org/10.1080/09585190802110075

Subramaniam, C., Shamsudin, F. M., Zin, M. L. M., Ramalu, S. S., \& Hassan, Z. (2016). Safety management practices and safety compliance in small medium enterprises. Asia-Pacific Journal of Business Administration, 8(3), 226-244. http://dx.doi.org/10.1108/APJBA-02-2016-0029

Sullivan, S. (2004). Making the Business Case for Health Productivity Management. Journal of Occupational Environmental Medicine, 46(6), 56-61.

Tam, C. M., \& Fung, W. H. (1998). Effectiveness of safety management strategies on safety performance in Hong Kong. Construction Management and Economics, 16, 49-55. http://dx.doi.org/10.1080/014461998372583

Tan-Wilhelm, D., Witte, K., Liu, W. Y., Newman, L. S., Janssen, A., Ellison, C., Yancey, A., Sanderson, W., \& Henneberger, P. K. (2000). Impact of a worker notification program: assessment of attitudinal and behavioural outcomes. American Journal of Industrial Medicine, 37, 205-213. 
http://dx.doi.org/10.1002/(SICI)1097-0274(200002)37

Teo, E. A. L., Ling, F. Y. Y., \& Chong, A. F. W. (2005). Framework for project managers to manage construction safety. International Journal of Project Management, 23(4), 329-341. http://dx.doi.org/10.1016/j.ijproman.2004.09.001

Wall, T. D., Jackson, P. R., \& Davids, K. (1992). Operator work design and robotics system performance: A serendipitous field study. Journal of Applied Psychology, 77, 353-362. http://dx.doi.org/10.1037/0021-9010.77.3.353

Waring, J. (1995). Safety Management Systems. London: Chapman and Hall.

Yadav, B. P., Siddiqui, N. A., \& Gautam, A. (2015). State of art review of hazards \& risk associated with viaduct work and suggestion to improve safety. International Journal of Advanced Engineering Technology, 6(4), $22-25$.

Yrjänheikki, E. (2011). Well-being at work on the Finnish agenda. NES2011-Wellbeing and Innovations through Ergonomics. Book of Abstracts, 17-23.

Zhang, D., Linderman K., \& Schroeder, R. G. (2012). The Moderating Role of Contextual Factors on Quality Management Practices. Journal of Operations Management, 30(1), 12-23. http://dx.doi.org/10.1016/j.jom.2011.05.001

Zohar, D. (1980). Safety climate in industrial organizations: Theoretical and applied implications. Journal of Applied Psychology, 65, 96-102. http://dx.doi.org/10.1037/0021-9010.65.1.96

Zohar, D. (2002). Modifying supervisory practices to improve sub-unit safety: A leadership-based intervention model. Journal of Applied Psychology, 87, 156-163. http://dx.doi.org/10.1037/0021-9010.87.1.156

Zohar, D., \& Luria, G. (2005). A multilevel model of safety climate: Cross-level relationships between organization and group-level climates. Journal of Applied Psychology, 90(4), 616-628. http://dx.doi.org/10.1037/0021-9010.90.4.616

\section{Copyrights}

Copyright for this article is retained by the author(s), with first publication rights granted to the journal.

This is an open-access article distributed under the terms and conditions of the Creative Commons Attribution license (http://creativecommons.org/licenses/by/4.0/). 